УДК 635-152

DOI: 10.25630/PAV.2019.24.37.001

\title{
Селекция:
}

\section{прикладная наука для импортозамещения}

Н.Н. Клименко, Г.И. Карлов

Приведены критерии, которые смогут сделать разрабатываемую Федеральную научно-техническую подпрограмму (ФНТП) по развитию селекции и семеноводства овощных культур эффективно функционирующей. Рассматриваются факторы, позволяющие российской селекции стать высококонкурентной отраслью.

Ключевые слова: овощи, селекция, семеноводство, государственная поддержка, ФНТП.

5 есспорный факт, что наука - двигатель прогресса. Также неоспоримый факт, что одна и та же наука в разных странах, в разных отраслях или даже в одной и той же отрасли, но в разных организациях дает различные результаты $[1,2,3]$. Это очень хорошо видно на примере работы селекционных компаний в овощеводстве [4]. Те компании, у которых имеется селекция, занимают особое, как правило, лидирующее положение на рынке или в каком-то его сегменте.

Сейчас, когда государство серьезно поддерживает развитие науки в сельском хозяйстве с целью понизить импортозависимость, важно чтобы эти усилия не пропали даром, и наука стала реальным инструментом повышения конкурентоспособности отечественной селекции овощных культур.

В этом году планируется запустить Федеральную научно-техническую подпрограмму (ФНТП) по развитию селекции и семеноводства овощных культур. Несколько аналогичных подпрограмм уже приняты и реализуются, например, по картофелю, сахарной свекле и т.д. Насколько они будут эффективно выполнены, зависит от многих факторов и условий. Для максимально эффективной реализации подпрограммы по селекции овощных культур важно разобраться не только в факторах и условиях, определяющих эту эффективность, но и в логике разработки самой ФНТП. Тогда российские овощеводы будут выращивать отечественные сорта и гибриды в больших объемах, и произойдет реальное импортозамещение.
В настоящее время в РФ только $20 \%$ овощей выращивается из семян отечественных сортов и гибридов, что говорит о серьезности проблемы и слабой конкурентоспособности селекционно-семеноводческих организаций. В мире уже давно сложился единый общий рынок семян овощных культур. В России он представлен более чем 75 иностранными компаниями: транснациональными, американскими, голландскими, французскими, японскими, корейскими и т.д., и огромным ассортиментом зарубежных сортов и гибридов (более 2600). Практически все они используются или использовались в товарном овощеводстве, в то время как из 6650 отечественных сортов и гибридов на полях сегодня можно найти единицы, а много и таких, которые никогда не занималини одного гектара [5]. На российском рынке семян работают все мировые лидеры по селекции овощных культур и естественно, что представлены они собственными селекционными разработками. Именно у них и покупают российские овощеводы $80 \%$ семян. Все иностранные компании - частные, имеют собственную селекцию и умеют активно работать на высококонкурентном рынке, т.к. конкурируют они прежде всего между собой.

Несколько слов о месте и роли селекции в иностранных компаниях. С нее начинается производственный цикл любой селекционно-семеноводческой компании: селекция - первичное семеноводство - товарное семеноводство очистка, доработка, фасовка семян продвижение сортов и гибридов на рынок - продажа семян. Собственные селекционные разработки и являются той основой, на которой строят компа- нии всю свою деятельность. При анализе рынка семян овощных культур четко видно, что в настоящее время именно уровень селекции определяет конкурентоспособность той или иной компании. На других этапах - семеноводство, доработка семян, продвижение, продажа - тоже можно получить определенное конкурентное преимущество, но оно не будет столь определяющим, как селекция. Сейчас основные объемы семян овощных культур выращиваются в одних и тех же мировых зонах, у одних и тех же производителей примерно одного и того же качества и по одним и тем же ценам. Дорабатываются семена практически до одинаковых стандартов качества, на очень близких по технологическим возможностям машинах. Если кто-то делает на каком-то из этих этапов оригинальный шаг, этот шаг быстро копируют конкуренты. А вот имея уникальный рыночный сорт или гибрид, компания может занять и довольно долго сохранять особое место на рынке.

Много примеров, когда гибриды находятся в продаже по 10 и более лет и когда компании десятилетиями являются лидерами на рынке семян по каким-то конкретным культурам за счет своей селекции. Именно поэтому селекция в любой компании относится к категории ноу-хау, является большим секретом и тщательно охраняется. Успех же самой селекции, а точнее ее способность создавать конкурентоспособные сорта и гибриды определяется тремя основными факторами: профессионализмом селекционеров; качеством, уникальностью селекционного материала и использованием современных инструментариев, в первую очередь биотехнологических методов. Иностранные компании, которые работают в России, все это имеют и многие из них в силу своих практически неограниченных финансовых возможностей, т.к. они являются частью транснациональных корпораций, задают тон мировой селекции по основным овощным культурам.

Интересен и еще один факт. Несмотря на свою мощь, иностранные частные селекционные компании во всех странах пользуются поддержкой государств. В развитых странах наиболее науко- и финансовоемкие и не только фундаментальные проблемы, но и отдельные прикладные вопросы для частных компаний решаются на основе государственных грантов в университетах или научных центрах. Плюс частные компании получают от государств информационную, методическую, кадровую и др. поддержку. В других странах: 
Китай, Южная Корея, страны Восточной Европы и т.д. государства ежегодно возвращают частным селекционным компаниям до 50\% средств, потраченных на селекцию, плюс также осуществляют другие виды поддержки. Также мы видим, что 80\% площадей овощных культур в РФ занято высококонкурентными зарубежными сортами и гибридами еще и благодаря целенаправленной работе мощных иностранных операторов рынка семян в лице частных компаний. У этих компаний имеются в РФ представительства, организованны дилерские сети, отстроены системы испытания и продвижения селекционных новинок. И борются они за отечественного овощевода не просто активно, а скорее агрессивно. Естественно, что подобных операторов рынка должна иметь и Россия. Также будет справедливо отметить, что иностранные компании дали отечественному овощеводству не только лучшие мировые селекционные достижения, но и современные технологии. Практика показывает, что российские овощеводы, которые используют лучшие сорта и гибриды и современные индустриальные технологии их выращивания, успешно вписались в рынок овощей и получают урожаи не ниже, а зачастую на уровне или даже выше, чем их зарубежные коллеги.

Сегодня встают закономерные вопросы: кто сможет достойно представлять российскую селекцию на жестком семенном рынке и кто будет так конкурировать с иностранными компаниями за отечественного овощевода, чтобы обеспечить планируемые показатели импортозамещения? Кроме российских частных компаний никто этого сделать не сможет. Тем более что других примеров в мире сегодня практически нет. Те отдельные, так называемые, государственные институты в некоторых странах бывшего соџлагеря, которые есть на рынке, давно по факту являются на 100\% частными компаниями. Слово государственный в названии, по их же признанию, они сохранили из маркетинговых соображений. Реальных примеров работы и тем более успешной государственных организаций непосредственно на семенном рынке овощных культур в мире сегодня нет. В России, как мы уже отмечали, тоже работают только частные иностранные компании, и конкурировать с ними могут только сильные, опирающиеся на современную науку, компании. И это уже происходит. Наглядный пример: из 20\% посевных площадей, занятых отечественными сортами и гибридами, в товарном овощеводстве около полови- ны - это селекционные разработки Агрохолдинга «Поиск», а одно из лучших хозяйств России ЗАО «Куликово», Дмитровского р-на, Московской области за последние 6 лет довело долю сортов и гибридов Агрохолдинга «Поиск» до 25\%. Это результат прямой конкуренции с иностранными компаниями, которые сегодня работают на российском рынке. Ранее, это хозяйство более 20 лет использовало только иностранные селекционные разработки. Есть и другие примеры российских частных компаний, которые также успешно конкурируют на российском рынке: в защищенном грунте - «Гавриш», по капусте - ООО «Селекционная станция имени Н.Н. Тимофеева» и др.

Дальше можно задать следующий вопрос: сколько нужно иметь российских частных компаний, чтобы обеспечить запланированный показатель импортозамещения? Ответ, казалось бы, прост: чем больше, тем лучше. Но, если мы планируем «выдавить» какую-то часть иностранных сортов и гибридов с наших полей, эти компании должны быть высококонкурентными. Таких компаний на сегодняшний день реально может быть единицы. Такое ограничение связано исключительно с объективными возможностями. У нас нет на сегодняшний день достаточного количества селекционеров, способных создавать сорта и гибриды требуемого уровня, а по некоторым культурам их вообще нет. Селекционер-практик и селекционер-теоретик - «две большие разницы». У первого - сорта и гибриды на полях, у второго - в отчетах, в статьях и в Госреестре. По сравнению с компаниями-лидерами мировой селекции у нас еще не наработан в нужном объеме и соответствующего качества исходный селекционный материал, равно как и инструментарий. Если у иностранных компаний биотехнология и генетические технологии, включая маркерную и геномную селекцию - это рутинный работающий инструмент селекции, у нас даже при наличии лабораторий они практически не встроены в реальную селекцию, нет достаточного количества соответствующих специалистов, а частные компании, ввиду ограниченных финансовых возможностей, только начинают осваивать эти методы. Также селекционер должен четко понимать, что эти методы лишь эффективный инструмент в его руках, а не замена селекции как таковой. Подтверждением этому служит тот факт, что на полях сегодня практически нет отечественных сортов и гиб- ридов, созданных с помощью современных биотехнологических методов. Но, несмотря на довольно сложную объективную ситуацию состояния отечественной селекции овощных культур, сегодня должна ставиться задача не только об увеличении доли отечественных селекционных разработок на российском рынке, но нужно говорить и о присутствии на мировом рынке. Ставить задачу развития отечественного экспортного потенциала селекции овощных культур просто необходимо. Этого требует и соответствующий указ президента [5]

Россия может и должна продавать за рубеж не только овощи собственной селекции, но и семена своих селекционных разработок. Отдельные частные российские компании уже делают в этом направлении первые шаги. Они испытывают свои сорта и гибриды в других странах и делают хоть и робкие, но всетаки попытки их продажи. Обобщая, можно сказать, что инструмент реализации ФНТП в лице частных селекционных компаний в РФ есть.

Далее встает следующий вопрос: как сделать эти компании высококонкурентными? Пути два. Или государству напрямую поддержать развитие частных компаний, или объединить усилия частных компаний и государственных научных организаций на основе государственно-частного партнерства (ГЧП). А еще лучше - использовать оба для более быстрого роста конкурентоспособности отечественных частных компаний. Сегодня в РФ сложилась уникальная ситуация. За постсоветское время в стране появилось и выросло несколько частных селекционных компаний, а также сохранилась сеть государственных научных организаций, которые в свое время были частью советской плановой индустрии производства овощей. Российские частные компании родились и выросли в условиях рынка, они живут и работают по образу и подобию иностранных частных компаний, вместе с которыми и составляют реальный рынок семян овощных культур. Селекция в частных компаниях направлена на удовлетворение требований рынка, т.к. только рынок является потребителем селекционных разработок. Вот здесь и встает еще один важный вопрос, а как оценивать результативность селекции? Ответ предельно прост. Посевные площади, занятые тем или иным сортом или гибридом показатель реального уровня селекции. Естественно, что по нему оцени- 
вается уровень и зарубежной селекции. Во всем мире селекция овощных культур - это прикладная наука, и результат ее деятельности физически измеряем и ценен для отрасли, поскольку это площади под конкретными гибридами.

Иначе дела обстоят с государственной селекцией. Объективности ради нужно признать, что у государственной науки сегодня есть достаточно современные лаборатории, есть возможность подготовки соответствующих кадров, которые могли бы решать задачи, поставленные рынком. Но работа государственных научных организаций и не только в овощеводстве, но и во многих других отраслях связана с рынком другой логикой и оценивается другими критериями. Научные организации работают, а главное финансируются по государственному заданию, создают научный продукт и потом предлагают его рынку, пытаясь при этом еще и стать его оператором. У этой логики сразу несколько слабых мест. Насколько государственные задания соответствуют требованиям рынка представляют немногие, а то и вообще никто не представляет. Не было и не будет механизмов, позволяющих быстро менять государственные задания под требования рынка, как это делают частные компании. Нет, и скорее всего по объективным причинам никогда не будет, эффективных механизмов внедрения научных разработок в производство. Ни центры по внедрению, ни МИПы, ни инжиниринговые центры, ни другие механизмы не смогли системно решить эту проблему. Результат - большинство научных разработок так и не доходят до внедрения, так как непонятно для кого и зачем они делались. Ну и главное - никогда государственная научная организация, по определению, не станет высококонкурентным оператором рынка. На протяжении последних 25 лет такие попытки делаются постоянно, но, мягко говоря, они низкоэффективны. Основной уставной деятельностью научной организации является генерация знаний и фундаментальные и прикладные научные исследования. Такие цели деятельности записаны в уставах не только российских, но и зарубежных научных организаций. Более того, во многих странах, включая западноевропейские, прямо прописан запрет на коммерческую деятельность научных организаций. Ситуацию усугубляет, как мы уже говорили, еще и то, что результативность государс- твенной селекции оценивается не по площадям посева, занятых селекционными разработками, в создании которых участвовали государственные научные организации, а по другим критериям: количеству публикаций, ссылкам на них, регистрации в Госреестре и т.д. В итоге выясняется, что даже хорошая оценка государственной селекции по этим показателям в реальности мало что дает для отрасли.

Сегодня в РФ наиболее реальным и перспективным направлением повышения конкурентоспособности отечественной селекции видится объединение усилий отечественных частных компаний и государственных научных организаций на основе ГЧП. Тем более что положительный опыт такой работы уже имеется. За последние годы из 650 сортов и гибридов, созданных Агрохолдингом «Поиск», более 130 сортов и гибридов было выведено совместно с Всероссийским НИИ овощеводства (ныне ВНИИО филиал ФНЦО). Причем это именно те сорта и гибриды, которые были нужны на рынке, и которые компания довела до отечественных овощеводов. Но, к сожалению, таких примеров немного. Такое на первый взгляд простое и правильное решение на практике довольно сложно осуществимо по целому ряду как объективных, так и субъективных причин. Надежда на ФНТП, которая может сделать отечественную селекцию конкурентоспособной. При ее реализации особо важно в максимально короткие сроки создать отечественных высококонкурентных операторов рынка за счет ГЧП. Это может быть сделано, если сама ФНТП будет разработана на основе требований рынка. Тогда можно будет определять конкретные показатели импортозамещения и быть уверенными, что они будут достигнуты.

В этом направлении Министерство науки и высшего образования и Агрохолдинг «Поиск» делают первый шаг - разрабатывают «Концепцию Проекта по импортозамещению сортов и гибридов овощных культур на основе государственно-частного партнерства государственных научных организаций и Агрохолдинга «Поиск» на 20192025 гг.» Министерство науки и высшего образования определило перечень участников Проекта: ФНЦ овощеводства, ФГБНУ ВНИИСБ, ФГБНУ ФИЦ ВИГРР (ВИР), ФГБНУ ВНИИБЗР, ФГБНУ ФНЦ имени И.В. Мичурина, которые могут ускорить создание высококонкурентных сортов и гибридов Агрохолдингом «Поиск». Планируется участие в этой работе и ФГБУ ВНИИКР. Очень важно при этом, что каждый занимается своим делом: научные организации - наукой; частная компания - бизнесом. Разработка концепции - важнейший этап совместной работы. Именно он закладывает будущее всего Проекта, поскольку речь идет об общем использовании материальных, финансовых и кадровых ресурсов. Разработанная и принятая концепция ляжет в основу конкретных планов и программ, реализация которых и должна обеспечить выполнение показателей импортозамещения.

Библиографический список

1.Клименко Н.Н., Ховрин А.Н., Огнев В.В. Агрохолдинг «Поиск». Селекция здоровья и долголетия // Картофель и овощи. 2017. № 9. С. 8-10.

2.Клименко Н.Н. От отечественных семян к продовольственной безопасности // Картофель и овощи. 2014. № 11. С. $2-4$

3.Клименко Н.Н. Государственно-частное партнерство - самый эффективный путь развития отечественной селекции овощных культур // Картофель и овощи. 2018. № 2. С. 2-6.

4.Клименко Н.Н. Конкурентоспособность - это не только селекцентры // Картофель и овощи. 2015. № 4. C. $2-6$

5.Монахос Г.Ф. Селекция и первичное семеноводство: состояние и перспективы // Картофель и овощи. 2017. № 3. С. 2-4

6.0 национальных целях и стратегических задачах развития Российской Федерации на период до 2024 года [Электронный ресурc] URL: http://kremlin. ru/events/president/news/57425 (Дата обращения: 03.02.19).

\section{Об авторах \\ Клименко Николай Николаевич, канд. с. - х. наук, директор Агрохолдинга «Поиск». E-mail: n.klimenko@poiskseeds.ru} Карлов Геннадий Ильич, доктор биол. наук, профессор, член-корреспондент РАН, директор ФГБНУ ВНИИСБ. E-mail: karlov@iab.ac.ru

Breeding: an applied scence for substitution of imports

N.N. Klimenko, $P h D$, director of Poisk Agro Holding. E-mail: n.klimenko@poiskseeds.ru G.I. Karlov, DSc, prof., corresponding member of the RAS, director of All-

Russia Research Institute of Agricultural Biotechnology. E-mail: karlov@iab.ac.ru Summary. Criteria which will be able to make the developed Federal scientific and technical subprogramme (FSTS) on development of selection and seed production of vegetable cultures effectively functioning are listed. The factors allowing Russian breeding to become a highly competitive industry are considered.

Keywords: vegetables, breeding, seed growing, state support, FSTS. 